\title{
Effect of Supplementation of Various Levels of Inulin on Growth Performance, Carcass Characteristics and Survivability in Raja II Broilers
}

\author{
T. Praveen", T. Munegowda, H.C. Indresh and Jayanaik \\ Department of Poultry Science, Veterinary College, KVAFSU, Bangalore, 560 024, India \\ *Corresponding author
}

A B S T R A C T

\begin{tabular}{l} 
K e y w o r d s \\
$\begin{array}{l}\text { Broiler, Inulin, } \\
\text { Growth, Carcass } \\
\text { characteristics. }\end{array}$ \\
Article Info \\
$\begin{array}{l}\text { Accepted: } \\
\text { 19 July } 2017 \\
\text { Available Online: } \\
\text { 10 September } 2017\end{array}$ \\
\hline
\end{tabular}

A biological trial was conducted to study the effect of supplementing various levels of in Raja II Broilers on growth performance, carcass characteristics and survivability parameters were studied from 1 to 42 days of age. 225 day old straight run Raja II broiler chicks were selected randomly and out of this 45 chicks were assigned randomly to each treatments: control (without inulin), control + 0.25 percent inulin $\left(\mathrm{T}_{2}\right)$, control +0.5 percent inulin $\left(\mathrm{T}_{3}\right)$, control +0.75 percent inulin $\left(\mathrm{T}_{4}\right)$ and control +1 percent inulin $\left(\mathrm{T}_{5}\right)$. The supplementation of various levels of inulin in broiler diets significant difference in body weight, feed intake and feed conversion ratio. Inulin also exhibited significant $(\mathrm{P} \leq 0.05)$ reduction in abdominal fat percentage. Other parameters viz., dressing per cent, giblets weights and survivability were unaffected by inulin supplementation. The results indicated that inulin have a better effect on growth performance, abdominal fat percentage.

\section{Introduction}

Poultry production has undergone an enormous expansion during the past decades throughout the world. As productivity improved, challenges also arise. In order to establish a more efficient and reliable feeding program for the chicken industry, certain aspects have to be addressed. For instance, the efficiency of poultry growth, the safety of the poultry products and the fixed cost of raising them (North and Bell, 1990). Antibiotics are widely used as a tool to prevent infections poultry, as well as a growth promoter. Current trends in poultry production are aimed at reducing the use of antibiotic growth promoters and increase the use of nonantibiotic feed additives. Prebiotics is one of the alternative feed additives that can be used to improve poultry heath and performance. Commercially available prebiotics are mostly fructo-oligosaccharides, isomalto-oligo saccharides, inulin, raffinose, lactulose, malto-oligosaccharides, guar gum, sucrose thermal oligosaccharides, galacto-oligo saccharides, transgalacto-oilgosaccharides, xylo-oligosaccharide.

Feeding inulin to broilers resulted in improved performance associated with significantly increased absorptive capacity of chicken gastrointestinal tract (GIT) due to increased length of both small intestine and colon. The fermentation activity inhibits the 
growth of harmful strains, selectively stimulate the growth of Bifidobacteria and Lactobacillus development in the gut (Roberfroid, 1998).

The objectives of the studies were to assess the effects of various levels of inulin on growth performance, carcass characteristics and Survivability in Raja II broilers.

\section{Materials and Methods}

\section{Experimental design and diets}

A total of 225 day old straight run Raja II broiler chicks were wing banded, weighed and randomly assigned to five treatment groups with three replicates in each treatment group and with 15 chicks in each replicate consisting of five dietary treatments: control (without inulin), control +0.25 percent inulin $\left(\mathrm{T}_{2}\right)$, control +0.5 percent inulin $\left(\mathrm{T}_{3}\right)$, control +0.75 percent inulin $\left(\mathrm{T}_{4}\right)$ and control +1 percent inulin $\left(\mathrm{T}_{5}\right)$.

The chicks were reared under deep litter system with all standard managemental practices till 6 weeks of age. Standard vaccination schedule were followed for immunizing the chicks. Birds were fed with broiler pre starter diet (0-7 days), starter diet (8-21 days) and finisher diet (22-42 days). The basal diet was formulated as per the specifications of BIS-2007.

Inulin sample required for the trial was procured from Quadragen Vet health Private Limited, Bangalore.

\section{Growth performance}

The data on growth performance parameters viz., Weekly Cumulative body weight, Weekly Cumulative feed consumption and feed conversion ratio were collected and analysed.

\section{Carcass characteristics}

Three birds from each replicate were randomly selected and a total of 45 birds were sacrificed on 42nd day of the experiment.

The data pertaining to carcass characteristics viz., dressing percentage, abdominal fat percentage and Giblet weight at the end of the experiment was collected and analyzed.

\section{Survivability}

Mortality in respective experimental group was recorded as and when the birds died. Mortality percentage in each treatment during the course of the experiment was recorded.

The dead birds were subjected to detailed postmortem examination to ascertain the cause of the death.

\section{Statistical analysis}

Data pertaining to various parameters obtained during the trial was analyzed statistically by ANOVA using SPSS 20 statistical software.

Differences between the means were tested using Duncan's Multiple Range Test at $\mathrm{P}<$ 0.05 .

\section{Results and Discussion}

In the present study, the results on the effect of supplementation of different levels of inulin on mean body weight of Raja II broilers were significantly different among different treatment groups during whole experimental period (Table 1).

During sixth week of age significantly higher body weight was recorded in the treatment group supplemented with 1 percent inulin $\left(\mathrm{T}_{5}\right)$ than the control group $\left(\mathrm{T}_{1}\right)$ and in support 
with the previous reports of Rebole et al., (2010) who compared various levels of inulin $(0,10$ and $20 \mathrm{~g} / \mathrm{kg})$ on the performance of broilers chickens assessed at 35days of age and indicated that broiler chicks fed with inclusion of $10 \mathrm{~g} / \mathrm{kg}$ of diet showed significantly $\quad(\mathrm{P}=0.043)$ improved body weight.

Similar result were recorded by Nabizadeh et al., (2012) conducted an experiment on inulin on performance of Ross broiler chicken and reported that supplementation of $1 \%$ inulin had significantly higher live body weight compared to those fed with 0 or $0.5 \%$ diets of inulin at 42 days of age.

Cetein et al., (2005) concluded that increase in body weight in birds was due to immunologic competence of prebiotics and its effect of increasing the active antibacterial substance.

In the present study during $3^{\text {rd }}, 5^{\text {th }}$ and $6^{\text {th }}$ week, feed consumption was significantly lower in inulin fed group when compared to the control group (Table 2) and in contrary with the previous reports of Van Leeuwen et al., (2006) reported that feeding of chicory fructan preparation (Raftifeed®IPE (IPE)) or inulin supplements showed significantly increased $(\mathrm{P} \leq 0.05)$ feed consumption in broilers fed the diets with $1 \%$ and $2 \%$ dietary inclusion of IPE inulin over the whole experimental period (1-35 days).

Similar results were recorded by Pawar et al., (2012) concluded that supplementation of chicory root powder inulin at 1.25, 2.5 and $3.75 \mathrm{~kg} / 100 \mathrm{~kg}$ of feed was useful in significantly improving the feed consumption in cobb 400 broilers at 42 days of age. Lower feed intake in inulin treatment groups might be due to the decrease in production of lactic acid in gut which may lead to reduced feed intake in broilers.
The results of the present study revealed that significant difference $(\mathrm{P} \leq 0.05)$ in mean FCR values among various treatment groups when compared to control group during $3^{\text {rd }}$, and $6^{\text {th }}$ week and non-significant during the rest of the weeks (Table 3) which were in contrary with the findings of Pawar et al., (2012) conducted study on cobb 400 broiler chicks by supplementing various levels of chicory root powder as a source of inulin $(1.25,2.5,3.75$ and $5 \mathrm{~kg} / 100 \mathrm{~kg}$ feed) and found non-significant differences with respect to average feed conversion ratio at the age of 7 to 42 days compared to control.

Similar results were recorded by Ali Mirza Aghazadeh and Elena Nabiyar (2015) conducted a trail in Ross 308 broilers diets supplemented with the chicory root extract inulin at the rate of $0 \%, 1.5 \%, 3 \%, 4.5 \%$ of total requirements for 42 days old of age and found non-significant difference in FCR compared to those of control diets.

The results of the present study revealed that non-significant difference in dressing percentage and giblets weight but there is significant reduction in abdominal fat percentage (Table 4).

The present findings of the study is in agreement with Elrayeh and Yildiz (2012) also revealed that supplementation of $0.7 \%$ inulin $+0.014 \% \beta$-glucan had no significant difference in carcass yield and giblets weight $(\mathrm{P}>0.05)$ in Ross broilers for 42 days of age.

Similar results were recorded by Pawar et al., (2012) conducted a trail in cobb 400 broiler chicks by supplementing various levels of chicory root powder as a source of inulin $(1.25,2.5,3.75$ and $5 \mathrm{~kg} / 100 \mathrm{~kg}$ feed) for 42 days of age and revealed non-significant difference in carcass yield and giblets weight, but significant decrease in abdominal fat pad percentage was observed. 
Table.1 Effect of supplementation of inulin on weekly cumulative body weight ( $\mathrm{g} / \mathrm{bird}$ ) of Raja II broilers

\begin{tabular}{|c|c|c|c|c|c|c|c|}
\hline $\begin{array}{l}\text { Experimental } \\
\text { group }\end{array}$ & $\begin{array}{c}\text { Description of the } \\
\text { treatment }\end{array}$ & $1^{\text {st }}$ Week & $2^{\text {nd }}$ Week & $3^{\text {rd }}$ Week & $4^{\text {th }}$ Week & $5^{\text {th }}$ Week & $6^{\text {th }}$ Week \\
\hline $\mathrm{T}_{1}$ & Control (without Inulin) & $92.51 \pm 1.9^{\mathrm{b}}$ & $209.08 \pm 5.3^{\mathrm{ab}}$ & $352.22 \pm 7.4^{\mathrm{ab}}$ & $587.97 \pm 10.8^{\mathrm{ab}}$ & $894.40 \pm 16.3^{\mathrm{b}}$ & $1234.93 \pm 16.5^{\mathrm{b}}$ \\
\hline $\mathrm{T}_{2}$ & Control $+0.25 \%$ Inulin & $86.42 \pm 1.6^{\mathrm{a}}$ & $195.82 \pm 5.4^{\mathrm{a}}$ & $330.15 \pm 9.1^{\mathrm{a}}$ & $556.82 \pm 14.1^{\mathrm{a}}$ & $837.86 \pm 18.1^{\mathrm{a}}$ & $1090.53 \pm 18.7^{\mathrm{a}}$ \\
\hline $\mathrm{T}_{3}$ & Control + $0.5 \%$ Inulin & $89.73 \pm 1.4^{\mathrm{ab}}$ & $215.06 \pm 5.3^{\mathrm{b}}$ & $357.42 \pm 8.2^{\mathrm{b}}$ & $583.33 \pm 12.7^{\mathrm{ab}}$ & $880.26 \pm 17.2^{\mathrm{ab}}$ & $1227.33 \pm 13.2^{\mathrm{b}}$ \\
\hline $\mathrm{T}_{4}$ & Control+ $0.75 \%$ Inulin & $86.68 \pm 1.7^{\mathrm{a}}$ & $207.68 \pm 5.7^{\mathrm{ab}}$ & $339.02 \pm 9.6^{\mathrm{ab}}$ & $566.08 \pm 14.2^{\mathrm{ab}}$ & $848.86 \pm 17.1^{\mathrm{ab}}$ & $1184.68 \pm 15.6^{\mathrm{b}}$ \\
\hline $\mathrm{T}_{5}$ & Control + 1\% Inulin & $92.53 \pm 1.7^{\mathrm{b}}$ & $216.82 \pm 4.8^{\mathrm{b}}$ & $361.46 \pm 7.6^{\mathrm{b}}$ & $597.35 \pm 12.8^{b}$ & $899.71 \pm 16.9^{b}$ & $1286.17 \pm 20.6^{\mathrm{c}}$ \\
\hline
\end{tabular}

Table.2 Effect of supplementation of inulin on weekly cumulative feed consumption (g/bird) of Raja II broilers

\begin{tabular}{|c|c|c|c|c|c|c|c|}
\hline $\begin{array}{c}\text { Experimental } \\
\text { group }\end{array}$ & $\begin{array}{c}\text { Description of the } \\
\text { treatment }\end{array}$ & $\mathbf{1}^{\text {st }}$ Week & $\mathbf{2}^{\text {nd }}$ Week & $\mathbf{3}^{\text {rd }}$ Week & $\mathbf{4}^{\text {th }}$ Week $^{\text {th }}$ & $\mathbf{5}^{\text {theek }}$ & $\mathbf{6}^{\text {th }} \mathbf{W e e k}$ \\
\hline $\mathrm{T}_{1}$ & Control (without Inulin) & $65.73 \pm 1.25$ & $214.15 \pm 10.52$ & $445.06 \pm 19.79^{\mathrm{b}}$ & $873.22 \pm 19.29$ & $1661.13 \pm 25.64^{\mathrm{b}}$ & $2734.84 \pm 21.31^{\mathrm{b}}$ \\
\hline $\mathrm{T}_{2}$ & Control + 0.25\%Inulin & $56.60 \pm 6.10$ & $199.60 \pm 6.58$ & $358.06 \pm 6.01^{\mathrm{a}}$ & $797.44 \pm 18.39$ & $1502.68 \pm 22.01^{\mathrm{a}}$ & $2447.15 \pm 43.04^{\mathrm{a}}$ \\
\hline $\mathrm{T}_{3}$ & Control + 0.5\%Inulin & $57.73 \pm 3.22$ & $211.44 \pm 9.66$ & $363.95 \pm 7.31^{\mathrm{a}}$ & $807.31 \pm 22.16$ & $1606.57 \pm 22.67^{\mathrm{ab}}$ & $2563.37 \pm 18.66^{\mathrm{a}}$ \\
\hline $\mathrm{T}_{4}$ & Control+ 0.75\% Inulin & $63.80 \pm 6.14$ & $220.22 \pm 23.01$ & $358.24 \pm 37.93^{\mathrm{a}}$ & $816.02 \pm 35.75$ & $1598.80 \pm 50.21^{\mathrm{ab}}$ & $2599.73 \pm 61.22^{\mathrm{ab}}$ \\
\hline $\mathrm{T}_{5}$ & Control + 1\% Inulin & $63.68 \pm 3.52$ & $212.57 \pm 3.35$ & $385.13 \pm 14.75^{\mathrm{ab}}$ & $835.15 \pm 26.31$ & $1599.75 \pm 41.03^{\mathrm{ab}}$ & $2596.97 \pm 64.49^{\mathrm{ab}}$ \\
\hline
\end{tabular}

Table.3 Effect of supplementation of inulin on weekly cumulative feed conversion ratio of Raja II broilers

\begin{tabular}{|c|c|c|c|c|c|c|c|}
\hline Experimental group & Description of the treatment & $\mathbf{1}^{\text {st }}$ Week & $2^{\text {nd }}$ Week & $3^{\text {rd }}$ Week & $4^{\text {th }}$ Week & $5^{\text {th }}$ Week & 6 $^{\text {th }}$ Week \\
\hline $\mathrm{T}_{1}$ & Control (without Inulin) & $0.71 \pm 0.01$ & $1.02 \pm 0.01$ & $1.26 \pm 0.05^{\mathrm{b}}$ & $1.48 \pm 0.04$ & $1.85 \pm 0.06$ & $2.16 \pm 0.04^{b}$ \\
\hline $\mathrm{T}_{2}$ & Control $+0.25 \%$ Inulin & $0.65 \pm 0.06$ & $1.02 \pm 0.02$ & $1.08 \pm 0.03^{\mathrm{ab}}$ & $1.43 \pm 0.04$ & $1.79 \pm 0.02$ & $2.01 \pm 0.02^{\mathrm{a}}$ \\
\hline $\mathrm{T}_{3}$ & Control + 0.5\% Inulin & $0.64 \pm 0.03$ & $0.98 \pm 0.01$ & $1.01 \pm 0.01^{\mathrm{a}}$ & $1.38 \pm 0.04$ & $1.82 \pm 0.03$ & $2.04 \pm 0.02^{\mathrm{ab}}$ \\
\hline $\mathrm{T}_{4}$ & Control+ $0.75 \%$ Inulin & $0.73 \pm 0.05$ & $1.05 \pm 0.10$ & $1.05 \pm 0.09^{\mathrm{a}}$ & $1.44 \pm 0.03$ & $1.88 \pm 0.01$ & $2.14 \pm 0.02^{b}$ \\
\hline $\mathrm{T}_{5}$ & Control + 1\% Inulin & $0.68 \pm 0.03$ & $0.98 \pm 0.04$ & $1.06 \pm 0.06^{\mathrm{ab}}$ & $1.40 \pm 0.07$ & $1.77 \pm 0.06$ & $2.06 \pm 0.05^{\mathrm{ab}}$ \\
\hline
\end{tabular}


Table.4 Effect of supplementation of inulin on carcass characteristics of Raja II broilers

\begin{tabular}{|c|c|c|c|c|c|c|}
\hline \multirow{2}{*}{$\begin{array}{c}\text { Experimental } \\
\text { group }\end{array}$} & \multirow{2}{*}{$\begin{array}{c}\text { Description of the } \\
\text { treatment }\end{array}$} & \multirow{2}{*}{$\begin{array}{c}\text { Dressing } \\
\text { percentage }(\%)\end{array}$} & \multirow{2}{*}{$\begin{array}{l}\text { Abdominal fat per cent } \\
\qquad(\%)\end{array}$} & \multicolumn{3}{|c|}{ Giblets weight (\%) } \\
\hline & & & & Heart & Liver & Gizzard \\
\hline $\mathrm{T}_{1}$ & Control (without Inulin) & $63.87 \pm 0.47919$ & $2.55 \pm 0.15^{\mathrm{c}}$ & $0.52 \pm 0.03$ & $2.70 \pm 0.10$ & $2.51 \pm 0.05$ \\
\hline $\mathrm{T}_{2}$ & Control $+0.25 \%$ Inulin & $64.37 \pm 0.83419$ & $1.52 \pm 0.22^{\mathrm{a}}$ & $0.61 \pm 0.04$ & $2.87 \pm 0.08$ & $2.69 \pm 0.11$ \\
\hline $\mathrm{T}_{3}$ & Control + 0.5\%Inulin & $64.73 \pm 0.39141$ & $1.77 \pm 0.19^{\mathrm{ab}}$ & $0.62 \pm 0.01$ & $2.92 \pm 0.10$ & $2.77 \pm 0.10$ \\
\hline $\mathrm{T}_{4}$ & Control+ $0.75 \%$ Inulin & $63.35 \pm 0.73256$ & $2.0 \pm 0.20^{\mathrm{abc}}$ & $0.61 \pm 0.05$ & $2.78 \pm 0.18$ & $2.84 \pm 0.15$ \\
\hline $\mathrm{T}_{5}$ & Control + 1\% Inulin & $63.79 \pm 0.74468$ & $2.18 \pm 0.23^{\mathrm{bc}}$ & $0.60 \pm 0.04$ & $2.92 \pm 0.13$ & $2.80 \pm 0.12$ \\
\hline
\end{tabular}

Table.5 Effect of supplementation of inulin on survivability per cent of Raja II broilers

\begin{tabular}{|c|c|c|}
\hline Experimental group & Description of the treatment & Survivability percentage \\
\hline $\mathrm{T}_{1}$ & Control (without Inulin) & $97.77 \pm 2.2$ \\
\hline $\mathrm{T}_{2}$ & Control + 0.25\%Inulin & $95.55 \pm 2.2$ \\
\hline $\mathrm{T}_{3}$ & Control + 0.5\%Inulin & $100 \pm 0.0$ \\
\hline $\mathrm{T}_{4}$ & Control+ 0.75\% Inulin \\
\hline $\mathrm{T}_{5}$ & Control $+1 \%$ Inulin & $97.77 \pm 2.2$ \\
\hline
\end{tabular}


The facts that decrease in abdominal fat in this study is probably because the amount of lipid that moved to the abdominal tissues decreased due to the lowering of blood lipid by dietary inulin.

The results of the study revealed nonsignificant difference in the Survivability of Raja II broilers under different treatment groups supplemented with inulin during 42 days of experimental period (Table 5). The present findings of the study is in agreement with Nabizadeh et al., (2012) reported that $0.5 \%$ and $1 \%$ inulin inclusion for 42 days had no effect on mortality in Ross broilers.

Similar results were recorded by Pawar et al., (2012) concluded that use of chicory root powder inulin at different levels has no effect on the health of the broilers.

\section{Acknowledgements}

The authors acknowledge the research facilities provided by the Karnataka Veterinary, Animal and Fisheries Sciences University, Bidar, India, for conducting this study.

\section{References}

Ali Mirza Aghazadeh, and Elena Nabiyar., 2015. The effect of chicory root powder on growth performance and some blood parameters of broilers fed wheat-based diets. J. Appl. Anim. Res., 43(4): 384-389.

BIS, 2007. Bureau of Indian Standards. Livestock feed and equipment systems sectional committee, FAD 5.

Cetein, N., Guclu, B.K.and Cetein, E., 2005. The effect of prebiotics and mannan- oligosaccharide on some haematological and immunological parameters in Turkey. J. Vet. Med, 52: 263-267.

Elrayeh, A.S., and Yildiz, G., 2012. Effects of inulin and $\beta$-glucan supplementation in broiler diets on growth performance, serum cholesterol, intestinal length, and immune system. Turkey J. Vet. Anim. Sci., 36(4): 388-394.

Nabizadeh, A., Gevorkyan, O. and Golian, A., 2012. Effect of inulin on some hematological, immunological parameters and broiler chickens performance. J. Anim. Vet. Adv, 11(18): 3304-3311.

North, M.O., and Bell, D.D., 1990. Commercial chicken production manual, $4^{\text {th }}$ edition, New York: Van Nostrand Rein hold.

Pawar, G.P., Ranade, A.S., Desai, D.N. and Avari, P.E., 2012. Effect of various levels of inulin on performance and gut health of broilers. XXXI Annual conference of Indian poultry science association and national symposium-2014.

Rebole, A., Ortiz, L. T., Rodríguez, M. L., Alzueta, C., TreviNo, J. and Velasco, S., 2010. Effects of inulin and enzyme complex, individually or in combination, on growth performance, intestinal microflora, cecal fermentation characteristics, and jejuna histomorphology in broiler chickens fed a wheat- and barley-based diet. Poult. Sci., 89(2): 276-286.

Roberfroid, M.B., 1998. Prebiotics and synbiotics: concepts and nutritional properties. British J. Nutr., 80(4): 197-202.

Van Leewen, P., Verdonk, M.A.J., Vanderklis, T.K. and Vanloo, J., 2006. Inulin improve performance of young broiler. In: XII European Poultry Conference (EPC), Verona, Italy, September, pp. 10-14.

\section{How to cite this article:}

Praveen, T., T. Munegowda, H.C. Indresh and Jayanaik. 2017. Effect of Supplementation of Various Levels of Inulin on Growth Performance, Carcass Characteristics and Survivability in Raja II Broilers. Int.J.Curr.Microbiol.App.Sci. 6(9): 1470-1475. doi: https://doi.org/10.20546/ijcmas.2017.609.179 